\title{
Development of a DNA Macroarray for Detection and Monitoring of Economically Important Apple Diseases
}

\author{
Peter Sholberg, Dan O'Gorman, and Karen Bedford, Agriculture and Agri-Food Canada, PARC, Summerland \\ $\mathrm{BC}$; and C. André Lévesque, Agriculture and Agri-Food Canada, ECORC, Ottawa ON
}

\begin{abstract}
Sholberg, P., O’Gorman, D., Bedford, K., and Lévesque, C. A. 2005. Development of a DNA macroarray for detection and monitoring of economically important apple diseases. Plant Dis. 89:1143-1150.

Short DNA gene sequences (oligonucleotides) from the ribosomal spacer regions of bacterial and fungal pathogens were used to identify and monitor economically important apple diseases. The oligonucleotides or probes were attached to a nylon membrane by an amine modified linker arm and arranged in a precise pattern to form an array for detecting five pathogens corresponding to five apple diseases. Initially the specificity of the probes was determined by hybridizing pure cultures of the pathogens to the probes. The DNA array correctly identified Botrytis cinerea, Penicillium expansum, Podosphaera leucotricha, Venturia inaequalis, and Erwinia amylovora and eliminated closely related species. When the array was used to monitor $V$. inaequalis ascospores collected from spore traps located in orchards, it confirmed the presence of ascospores as predicted by the disease forecasting model. Preliminary tests to quantify P. leucotricha populations using grayscale values was effective to 20 conidia per leaf disk. The DNA array is a promising new detection system for accurate identification of several pathogens in a single test with the potential for being a new tool for epidemiological studies.
\end{abstract}

The lack of fast, accurate, and reliable means for detecting and monitoring plant pathogens is a major limitation of integrated disease management. Molecular methods have emerged that are faster and more accurate than traditional culturing techniques for fungi and bacteria $(19,20,37)$. Such methods often rely on efficient recovery and purification of pathogen DNA that can be used in polymerase chain reaction (PCR) assays to identify fungi to the species level (21). Most of these PCR assays are designed for the identification of one (6) or small numbers of species at a time such as the Neofabraea pathogen complex in pome fruit (12). Using the DNA array system will allow for simultaneous identification of bacterial and fungal pathogens in a single test. These tests can also utilize pathogen DNA extracted directly from buds, blossoms, and fruit tissue or from spore traps $(3,9,39)$ and eliminate the need for the isolation and culturing of the pathogens.

Many molecular studies that have utilized PCR or DNA array-based methods for the detection or identification of microorganisms have been based primarily on

Corresponding author: Peter Sholberg

E-mail: sholbergp@agr.gc.ca

Accepted for publication 9 June 2005.

DOI: 10.1094/PD-89-1143

Department of Agriculture and Agri-Food, Government of Canada. () Minister of Public Works and Government Services Canada 2005 sequence analysis of one or several gene regions $(5,8,17,25,31,32)$. One of the most common DNA targets for these kinds of studies is ribosomal DNA (rDNA). Spacer regions within the rDNA have been shown to be valuable in genus and species resolution in taxonomic studies $(2,29,33,38)$. Comparison of rDNA target sequences can also be made with a large rDNA sequence collection within the GenBank database (National Center for Biotechnology Information [NCBI], Bethseda, MD) since this is the most common region sequenced in taxonomic studies.

DNA macroarrays were first developed in the medical field to identify mutations associated with cystic fibrosis (15), in ecological studies to determine microbial populations (36), and in the area of food safety to identify the foodborne pathogen Escherichia coli O157:H7 (4). DNA arrays have also been developed for agriculture to identify oomycete species (17), fungal pathogens of lettuce (35) and tomato (18), bacterial pathogens of potato (8), and nematodes (34). DNA array systems use amplified and labeled samples of DNA to act as probes in an array with specific oligonucleotides anchored to a solid support, such as nylon membranes (macro) or glass slides (micro). The results can either be captured on X-ray film, where a positive reaction is recorded as a light gray to black dot while a negative reaction is white, or scanned directly if the DNA label is fluorescent. The hybridization intensity can be converted to grayscale values to indicate reaction strength for quantification of the results (8). A preliminary report on the design and testing of a DNA array diagnostic system for use on apple diseases has been published (24).

The goal of this study was to develop and test a DNA macroarray system based on the reverse dot-blot hybridization technique. The prototype system will be composed of a nylon membrane with an array of oligonucleotide probes specific for the major apple pathogens that cause apple scab, blue mold, gray mold, powdery mildew, and fire blight. Its design will involve testing several templates with both nonspecific and species-specific bacterial and fungal probe sequences from the ribosomal internal transcribed spacer (ITS) regions placed on nylon membranes. The array will be tested with DNA extracted directly from plant tissue or spore trap samples and used to monitor and quantify some of these pathogens in the orchard to show the versatility of the DNA array for use in epidemiological studies.

\section{MATERIALS AND METHODS}

Culture collection. A representative culture collection of apple pathogens consisting of both fungal and bacterial species was assembled (Table 1). Stock cultures were stored on agar slants at $2^{\circ} \mathrm{C}$ or stored at $-70^{\circ} \mathrm{C}$ in a $30 \%$ glycerol solution.

DNA extraction from reference cultures. Fungal and bacterial isolates were grown in liquid culture until sufficient biomass was available for DNA extraction. Approximately 50 to $200 \mathrm{mg}$ of cultured tissue was transferred into 2-ml tubes for extraction using a commercial DNA purification kit. (Bio 101 Inc., Vista, CA). The DNA purification protocols supplied with the kit for either fungi or bacteria were followed, and DNA was eluted in 100- $\mu$ l volumes and stored at $-20^{\circ} \mathrm{C}$ until required.

PCR amplification. DNA from pure culture was amplified using PCR in $25-\mu \mathrm{l}$ volumes containing: 10 to $20 \mathrm{ng}$ of DNA, $1 \times$ buffer $\left(75 \mathrm{mM}\right.$ Tris, $20 \mathrm{mM}\left(\mathrm{NH}_{4}\right)_{2} \mathrm{SO}_{4}$, $0.01 \%$ Tween 20), $1.6 \mathrm{mM} \mathrm{MgCl} 2,1.5 \mathrm{mM}$ dNTP mix, $0.4 \mu \mathrm{M}$ each, forward and reverse primers, and 1 unit of UltraTherm DNA polymerase (TetraLink International, Buffalo, NY). For labeling of PCR product with digoxigenin (Dig) (Roche Diagnostics $\mathrm{GmbH}$, Mannheim, Germany), a $1.5 \mathrm{mM}$ concentration of Dig-dUTP mix was also added to the reaction mixture. Universally conserved ribosomal primer pairs used to 
amplify the DNA were ITS-1 and ITS-4 (38) for fungal DNA, and ITS-16 and ITS23 (22) for bacterial DNA. Amplification was performed on a GeneAmp 2400 ther- mal cycler (Applied Biosystems, Foster City, CA) with variable cycle conditions depending on the primers used. For the universal fungal primers (ITS-1 and ITS-
Table 1. Isolate information for fungal and bacterial species used in this study

\begin{tabular}{|c|c|c|c|c|}
\hline Species & Accession no. & Collection ID & Origin & $\begin{array}{l}\text { Host or } \\
\text { substrate }\end{array}$ \\
\hline Botrytis cinerea & AY818329 & PLS B27 & BC, Canada & Apple \\
\hline B. cinerea & AY818327 & PLS 1705 & BC, Canada & Black berry \\
\hline B. cinerea & & DAOM 57869 & BC, Canada & Tulip \\
\hline B. cinerea & & DAOM 189076 & PEI, Canada & Potato \\
\hline B. tulipae-like & AY818328 & PLS 1767 & BC, Canada & Apple \\
\hline B. tulipae-like & AY818325 & PLS B-43 & BC, Canada & Apple \\
\hline B. tulipae & AY818326 & PLS 1663 & BC, Canada & Tulip \\
\hline B. tulipae & AY818336 & GAC WSU-5 & WA, USA & Tulip \\
\hline B. tulipae & & GAC WSU-6 & WA, USA & Tulip \\
\hline B. streptothrix & & DAOM 37579 & ON, Canada & Blue cohosh \\
\hline B. fabae & AY818333 & DAOM 137563 & NS, Canada & Faba bean \\
\hline B. crystalline & AY818334 & DAOM 196839 & Unknown & Unknown \\
\hline B. aclada & AY818335 & DAOM 196801 & BC, Canada & Allium cepa \\
\hline B. squamosa & AY818331 & DAOM 211643 & ON, Canada & Spruce \\
\hline B. porri & AY818332 & DAOM 212258 & NS, Canada & Garlic bulb \\
\hline Penicillium expansum & & PGS 5-97 & WA, USA & Apple \\
\hline P. expansum & & PGS 98-95 & WA, USA & Apple \\
\hline P. expansum & AY818337 & PLS 1026-1 & BC, Canada & Apple \\
\hline P. expansum & AY818338 & PLS 1519 & BC, Canada & Apple \\
\hline P. solitum & AY818340 & PGS 22-97 & WA, USA & Apple \\
\hline P. solitum & & PGS 99-001 & WA, USA & Apple \\
\hline P. solitum & AY818339 & PLS 1045-k & BC, Canada & Apple \\
\hline$P$. aurantiogriseum & AY818341 & PGS 92-27 & WA, USA & Apple \\
\hline P. commune & AY818342 & PGS 91-38 & WA, USA & Apple \\
\hline$P$. bilaiae & AY818343 & DAOM 197974 & $\mathrm{AB}$, Canada & Soil \\
\hline P. glabrum & & DAOM 211751 & AB, Canada & Pine \\
\hline P. lividum & & DAOM 174550 & $\mathrm{AB}, \mathrm{Canada}$ & Soil \\
\hline P. implicatum & & DAOM 167025 & QB, Canada & Maple \\
\hline P. turbatum & & DAOM 18094 & ON, Canada & Lettuce \\
\hline Podosphaera leucotricha & AY157844 & PLS AMP-1 & BC, Canada & Apple \\
\hline P. leucotricha & & PLS AMP-2 & BC, Canada & Apple \\
\hline P. leucotricha & AY157845 & PLS PPM-1 & BC, Canada & Pear \\
\hline P. leucotricha & & PLS PPM-2 & BC, Canada & Pear \\
\hline P. clandistina & AY818344 & PLS Pc1 & BC, Canada & Cherry \\
\hline Uncinula necator & AY818345 & PLS Un-1 & BC, Canada & Grape \\
\hline Sphaerotheca fuliginea & & PLS Sfn-1 & BC, Canada & Pansy \\
\hline Erysiphe cichoracearum & & PLS Ec-dl1 & BC, Canada & Dandelion \\
\hline E. cichoracearum & & PLS Ec-sh1 & BC, Canada & Shasta daisy \\
\hline E. graminis & & PLS Eg-1 & BC, Canada & Turfgrass \\
\hline Ventura inaequalis & & PLS 1969 & BC, Canada & Apple \\
\hline$V$. inaequalis & & PLS 1971 & BC, Canada & Apple \\
\hline V. inaequalis & & PLS 1972 & BC, Canada & Apple \\
\hline V. inaequalis & & PLS 1818 & BC, Canada & Apple \\
\hline$V$. pirina & & RS $10-18$ & OR, USA & Pear \\
\hline$V \cdot$ pirina & & RS 11-1 & OR, USA & Pear \\
\hline Erwinia amylovora & & PLS 1280 & BC, Canada & Apple \\
\hline E. amylovora & & PLS 1477-1 & BC, Canada & Apple \\
\hline E. amylovora & & AS EaG-5 & ON, Canada & Pear \\
\hline E. carotovora & & BC E-1 & BC, Canada & Potato \\
\hline E. carotovora & & BC E-161 & BC, Canada & Potato \\
\hline Pantoea agglomerans & & PLS 2092 & BC, Canada & Grape \\
\hline Escherichia coli & & PD B-62 & BC, Canada & Blueberry \\
\hline E. coli & & PD K-3 & BC, Canada & Blueberry \\
\hline Bacillus sp. & & PLS 2061 & BC, Canada & Grape \\
\hline $\begin{array}{l}\text { Pseudomonas syringae } \\
\text { pv. syringae }\end{array}$ & & MM W4-N108 & OR, USA & Cherry \\
\hline$P$. viridiflava & & PLS ARS-4 & BC, Canada & Apple \\
\hline P. fluorescens & & MMc 63-49 & Unknown & Peat bog \\
\hline
\end{tabular}

${ }^{a}$ AS = from collection of Antonet Svircev, Agriculture and Agri-food Canada, Vineland Station, ON, Canada; BC = from collection of Bob Copeman, University of British Columbia, Vancouver, BC, Canada; DOAM = Department of Agriculture Ottawa Mycological collection no., Eastern Cereal and Oilseed Research Centre, Ottawa, Ontario, Canada; GAC = from collection of Gary Chastagner, Washington State University Research and Extension Center, Puyallup, WA, USA; MM = M. Margaret, Oregon State University, Corvallis, OR, USA; MMc $=$ M. McClough; PD = from collection of Pascal Delaquis, Agriculture and Agri-Food Canada, Summerland, B.C., Canada; PGS = from collection of Peter Sanderson, Washington Tree Fruit Research Commission, Wenatchee, WA, USA; PLS = from collection of Peter Sholberg, Agriculture and Agri-Food Canada, Summerland, BC, Canada; RS = from collection of Robert Spotts, Oregon State University, Hood River, OR, USA.
4), the conditions were: $95^{\circ} \mathrm{C}$ for $2 \mathrm{~min}$ followed by 35 cycles of $95^{\circ} \mathrm{C}$ for $30 \mathrm{~s}$, $58^{\circ} \mathrm{C}$ for $30 \mathrm{~s}$, and $72^{\circ} \mathrm{C}$ for $1 \mathrm{~min}$, and a final extension cycle of $72^{\circ} \mathrm{C}$ for $7 \mathrm{~min}$. Amplification using the bacterial primers (ITS-16 and ITS-23) used similar conditions with a lower annealing temperature of $50^{\circ} \mathrm{C}$. Amplification products were purified with the Qiaquick PCR purification kit (Qiagen Inc., Mississauga, ON, Canada) following the protocol supplied by the manufacturer to remove unused PCR reagents. The concentration of amplification products was estimated on a $1.5 \%$ agarose gel with Low Mass ladder (Invitrogen, Gaithersburg, MD).

A nested PCR was conducted using the same cycling conditions as described above for both rounds of amplification of fungal DNA from orchard samples. The primers ITS-F (11) and UN28S-22 (1) were paired in the first round. The amplification product of the first round of PCR was diluted $1: 10$, and $0.5 \mu \mathrm{l}$ of this product was used as template in a second PCR reaction. The nested primers UN18S-42 (1) and ITS-4 were used simultaneously to amplify and label DNA for hybridization probing, using the DNA array as explained below. Nested PCR of field samples was not required for the detection of bacterial DNA.

DNA sequencing. Sequence reaction mixtures contained 15 to $20 \mathrm{ng}$ of purified DNA. The primers ITS- 1 and ITS- 4 were used in separate reactions with the Big Dye Terminator sequencing mix (Applied BioSystems) to sequence the ITS-1, 5.8 S, and ITS-2 regions of the rDNA of fungal apple pathogens. The sequencing reactions were performed in a GeneAmp 2400 programmed for 25 cycles of $95^{\circ} \mathrm{C}$ for $30 \mathrm{~s}$ followed by $50^{\circ} \mathrm{C}$ for $15 \mathrm{~s}$ and an extension at $60^{\circ} \mathrm{C}$ for $2 \mathrm{~min}$. Extension products were precipitated in the presence of 1:10 volume of $3 \mathrm{M}$ sodium acetate, 3 volumes of $95 \% \mathrm{ETOH}$, incubated at room temperature for $15 \mathrm{~min}$ and centrifuged at $12,000 \times g$ for $20 \mathrm{~min}$. The pellets were washed in $70 \% \mathrm{ETOH}$, air-dried on the bench top, and then resuspended in template suppression reagent (TSR, Applied BioSystems). An ABI 310 Genetic Analyzer (Applied BioSystems) was used for sequence detection and acquisition. Sequence data were edited manually using Sequence Navigator software (Applied BioSystems). Ambiguities identified in the sequence data were resolved by comparison with reverse complementary sequences. Multiple sequences for each isolate were compiled to generate a single consensus sequence that was entered into our database for analysis.

Sequence analysis and oligonucleotide probe selection. Consensus sequences were searched by BLAST using the GenBank database to confirm the identity of the pathogen species. Consensus sequences for isolates of particular patho- 
gens were also aligned in Clustal X (SGI, Mountain View, CA) with sequences of related species obtained in this study or retrieved from GenBank. Phylogenetic trees were generated for species identification using the neighbor joining method (27), and confidence values for grouping were derived with the Bootstrap method (7) with 1,000 replications. Sequence alignments were analyzed visually to identify regions exhibiting unique polymorphisms which were marked as sites for the selection of species-specific oligonucleotide probes for a DNA array (Table 2). Final probe selection and design were carried out using Oligo 6 software (National Biosciences, Hamel, $\mathrm{MN}$ ) to ensure uniform melting temperatures and the absence of duplex formation. Additional confirmation was gained by conducting BLAST searches of probe sequences to avoid selecting rDNA homologous to other species in the GenBank database.

DNA array construction. Oligonucleotide probes were ordered from Qiagen Operon (Qiagen) with a 5' amine modification to allow immobilization on a nylon membrane. The probes were diluted to a final concentration of $40 \mu \mathrm{M}$ in sodium bicarbonate buffer ( $\mathrm{pH}$ 8.4) plus $0.004 \%$ bromophenol blue, and then placed in microplate wells in a sterile 384-well microplate following a predesigned array template that clustered together oligonucleotide probes targeting a common pathogen. The oligonucleotide probes were spotted on Immunodyne ABC membranes (PALL Europe Ltd., Portsmouth, England) with a VP 384 Library Copier (V\&P Scientific Inc., San Diego, CA). Multiple copies of the membrane were printed and airdried for $10 \mathrm{~min}$ and transferred to blocking solution $(2 \times$ sodium citrate [SSC] [ $1 \times$ SSC: $0.15 \mathrm{M} \mathrm{NaCl}$ and $0.015 \mathrm{Na}$-citrate], $1 \%$ skim milk powder [wt/vol], and $0.05 \%$ Tween 20) and shaken for $20 \mathrm{~min}$. Following blocking, the membranes were rinsed twice in $2 \times \mathrm{SSC}$, air-dried, and stored in an envelope at room temperature until needed.

Oligonucleotide probes were designed for the major apple pathogens occurring in North America (Table 2). Multiple probes were selected for each pathogen and designed with comparable hybridization melting temperatures. Probes were attached to the array membrane in groups that targeted specific pathogens. Probes for closely related species were also placed adjacent to each other to aid in interpreting the hybridization results. Several versions of the same probe were designed with different melting temperatures (varying by $1{ }^{\circ} \mathrm{C}$ ), and were incorporated on the initial prototype of the DNA array. A second array was then constructed using only those probes that functioned optimally when hybridized at $60^{\circ} \mathrm{C}$.

Genus-specific probes (Bot-All-H1 and Bot-All-H1B) were designed to detect all species of Botrytis in addition to the fungal pathogen-specific probes for gray mold (B. cinerea), blue mold (Penicillium expansum), apple powdery mildew (Podosphaera leucotricha), and apple scab (Venturia inaequalis) (Table 2). The two fungal probes (Univ-H1U and Univ-H1L) on the array were designed to detect rDNA from all fungal species and were both modified from the forward PCR primer, UN-18S42 (1). Bacterial probes (Bact-H1, Bact-H2, and Bact-H3) were designed to detect a wide range of bacterial species and were selected from the $5^{\prime}$ and $3^{\prime}$ ends of the amplified ITS fragment.

Hybridization and detection. Hybridizations of the membranes were conducted at $60^{\circ} \mathrm{C}$ following a protocol described by Fessehaie el al. (8). Chemiluminescent detection of the hybridized Dig-dUTPlabeled target DNA of fungal and bacterial pathogens of apple (Table 1) was carried out following manufacturer's protocol, using anti-Dig alkaline phosphatase conjugate and a 1:1,000 dilution of CDP-Star substrate (Roche Diagnostics $\mathrm{GmbH}$ ). Membranes were sealed in domestic plastic wrap and immediately exposed to X-ray film (Blue Sensitive MB-1; Medtech Marketing Ltd., Burnaby, BC, Canada) for 60 min. After development of the film, DIGamplified products that hybridized appeared as dots of varying gray intensities. The films were scanned on an Arcus II scanner (Agfa Inc., Toronto, Canada) using the transparency mode. The public domain software ImageJ 1.30v (National Institutes of Health, Bethesda, MD) was used to read individual hybridization signals. Data were recorded as average gray values for each dot with numbers ranging from 0 (completely white) to 255 (completely black).
Quantification of DNA array hybridization signal with Podosphaera leucotricha. The quantification capabilities of the DNA array hybridization were investigated using probes specific for apple powdery mildew. A single apple leaf was collected from a 6-week-old 'McIntosh' apple seedling in the greenhouse with visible powdery mildew symptoms. Conidia were washed from the leaf surface by repeatedly pipetting $2 \mathrm{ml}$ of $0.01 \%$ Tween 20 across the surface and collecting it in a sterile petri dish. A hemacytometer was used to estimate the conidial concentration, and a 10 -fold serial dilution of the conidia was then carried out. From each dilution, 100 $\mu \mathrm{l}$ of conidial suspension was used to inoculate the surface of a sterile leaf disk $(0.75 \mathrm{~mm})$ and a spore trap I-rod, which were allowed to dry in a laminar flow hood. The final concentrations of conidia per leaf disk or I-rod were: $2.0 \times 10^{5}, 2.0 \times$ $10^{4}, 2.0 \times 10^{3}, 2.0 \times 10^{2}, 2.0 \times 10^{1}, 2.0 \times$ $10^{\circ}$, and 0 conidia. A single leaf disk or Irod was used per extraction, and DNA was eluted in 100- $\mu$ l volumes. Nested PCR was carried out as described earlier and subsequently used in hybridization reactions with the DNA array. Hybridization results were converted to grayscale values (ImageJ $1.30 \mathrm{v}$ software) and were used to identify lower detection limits and to generate a standard series for comparative quantification purposes.

Field monitoring. Apple leaves and blossoms were collected at regular intervals in the 2002 and 2003 growing seasons, and DNA was isolated from these samples using a slightly modified version of the FastDNA kit (Bio 101 Inc.) protocol with an additional wash step using $300 \mu \mathrm{l}$

Table 2. Probe name, target species and probe sequence of species targeted for detection by the DNA array

\begin{tabular}{lll}
\hline Probe name & Target species & Probe sequence \\
\hline UN-H1U & Nonspecific fungal rDNA & CGTAACAAGGTTTCCGTAGG \\
UN-H1L & Nonspecific fungal rDNA & ACCTACGGAAACCTTGTACGA \\
Bot-all-H1u & Botrytis spp. & TTAGCTTGGTATTGAGTCTATGT \\
Bot-all-H21 & Botrytis spp. & ACATAGACTCAATACCAAGCTAA \\
BC-H2d & B. cinerea & TATGCTCGCCAGAGAATACCAAA \\
BC-H3d & B. cinerea & GCTCGCCAGAGAATACCAAAAC \\
BT-H1d & B. tulipae and B. tulipae-like & TATGCTCGCCAGAGAAAACAAA \\
BT-H2d & B. tulipae and B. tulipae-like & CTCGCCAGAGAAAACCAAACT \\
BP-H1c & B. porri & CGTGCTCGCCAGAGAAAACC \\
PE-H1c & Penicillium expansum & CCGTGTTTATTTACCTCGTTGC \\
PE-H2c & P. expansum & CCCGAACTCTGCCTGAAGATT \\
PE-H3U & P. expansum & TGCCTGAAGATTGTCGTCTG \\
PM-H2b & Podospora leucotricha & GTGTGAACTATTTGTGTTGCTTT \\
PM-H3L & P. leucotricha & TTAATTTAGACTCAGACTGCAC \\
PM-H3U & P. leucotricha & GTGCAGTCTGAGTCTAAATTAA \\
PM-H4 & P. leucotricha & CACGCAGGACACTCGTTCTG \\
VI-H1b & Venturia inaequalis & CGCATCCCCACCCTCTGTAAC \\
VI-H2b & V. inaequalis & GAAGTCTGAGAACAAGTTAAATAAA \\
VI-H3b & V. inaequalis & GCTCGGAGTGTCTGTCGGC \\
VI-H4b & V. inaequalis & GCCCGAACCTATATTTACAAG \\
Bact-H1 & Nonspecific bacterial rDNA & CACCGTGTACGCTTAGTCGC \\
Bact-H2 & Nonspecific bacterial rDNA & GTTGGATCACCTCCTTACCTG \\
Bact-H3 & Nonspecific bacterial rDNA & GTGAAAGGGCGGAGTCCTA \\
EA-H1 & Erwinia amylovora & TAGACGAAGGGGACACGGT \\
EA-H3d & E. amylovora and E. pyrifoliae & AAGATACCTTCCGGCGCAGTG \\
EA-H4C & E. amylovora & GAAAGGTGTCGCTAAAAATATCTT \\
\hline
\end{tabular}


of $6 \mathrm{M}$ guanidine thiocyanate just prior to the kit's wash step. DNA was also isolated from several I-rods recovered from spore traps (GRIPST-2000 Rotation Impaction Sampler, Aerobiology Research Laboratories, Nepean, Ontario, Canada) located at the PARC and Summerland (Garnet Valley), BC, Canada orchards. The spore traps were set to run for $1 \mathrm{~min}$ out of every 10 , and the I-rods were sampled daily through bloom and weekly thereafter throughout the growing season. The I-rods were processed by placing them directly into DNA extraction tubes supplied with the FastDNA kits and following the manufacture's protocol using CLS-Y buffer and a \#3 lysing matrix combination $(0.64-\mathrm{cm}$ sphere plus garnet matrix) supplied with the kit. The DNA was amplified and simultaneously labeled with Dig-dUTP and hybridized with the DNA macroarray as described earlier.

Temperature, relative humidity, and leaf wetness data were collected using miniature data loggers (Model 450 WatchDog Data Logger, Spectrum Technologies, Plainfield, IL) at orchards with spore traps. Weather data were analyzed with SpecWare 6.0 software (Spectrum Technologies) and input into the apple/pear IPM software package (Spectrum Technologies) that was designed to forecast infection periods for both apple scab and fire blight. The weather instrumentation did not have an accompanying apple powdery mildew predictive model, and therefore the grape powdery mildew software package (Spectrum Technologies) was used as a substitute. Results obtained with the predictive models were compared with DNA array results from spore trap samples, and for apple scab, on visual confirmation of number of mature ascospores released from leaves collected from the orchard floor (10). DNA array results were compared with the predictive models for powdery mildew and apple scab for two consecutive growing seasons (2002 and 2003) and for one season (2003) for fire blight.

\section{RESULTS AND DISCUSSION}

Specificity of the DNA array for apple plant pathogens. A selected list of bacterial and fungal species that hybridized with the final DNA array prototype is shown (Fig. 1). The array was specific for pathogens that cause gray mold, blue mold, powdery mildew, apple scab, and fire blight in Canada (13). The nonspecific universal fungal probes (Univ-H1U, UnivH1L) produced strong positive reactions with the full range of fungal species tested, showing by comparison the specificity of the species-specific probes.

Hybridization with the Botrytis genus probes was limited to only the Botrytis species tested, with a few exceptions (Fig. 1). Sequences were identified and probes designed to differentiate between the two dominant Botrytis spp. isolated from apple. The probes for the Botrytis spp. (Bot-allH1u, Bot-all-H21) exhibited limited specificity as was predicted from the sequence data but could easily discriminate between the dominant Botrytis spp. isolated from apple in our laboratory, $B$. cinerea and a $B$. tulipae-like species. The ITS regions from nine Botrytis spp. showed that while this region could discriminate among groups of Botrytis spp., it could not completely differentiate among individual species. The $\beta$-tubulin gene is an alternative region that could be exploited for molecular detection purposes. Although less commonly used for phylogenetic studies than the ITS region, the $\beta$-tubulin gene has been shown to contain significant sequence variability, allowing for, in some cases, greater phylogenetic resolution than that produced by either mitochondrial DNA or the ITS region $(5,23)$.

Probes designed for Penicillium expansum (PE-H1c, PE-H2c, PE-H3U) reacted specifically with $P$. expansum but not with the other Penicillium spp. (Fig. 1). P. expansum, the dominant blue mold pathogen of apple, was the only Penicillium spp. targeted on the array. Identification and differentiation of Penicillium spp. based on colony morphology and growth characteristics is problematic $(26,28)$; therefore, any technique that aids in species identification is important. Probes designed for P. expansum were selected from unique ITS gene sequences allowing differentiation from other Penicillium spp. that cause apple decay. Although the ITS region of the ribosomal gene was effectively used in this study to design $P$. expansum-specific probes, and has also been used successfully to develop other Penicillium speciesspecific assays (25), it does not appear that the ribosomal spacers can be universally applied for species identification over this large and complex genus (30). The $\beta$ tubulin gene is likely a better target for discrimination among large numbers of Penicillium spp. Resolving power at the species level was demonstrated by Seifert and Louis-Seize (30), who used $\beta$-tubulin gene to separate closely related Penicillium spp. in combination with mycotoxin profiles and physiological and micromorphological characters. In addition, research conducted on several Penicillium spp. pathogenic on apple, including $P$. expansum, $P$. commune, $P$. solitum, and $P$. arrantiogriseum, showed that species identification was possible based on partial $\beta$ tubulin sequence data (31).

The reaction of powdery mildew probes to samples of powdery mildew DNA collected from various host plants (apple, pear, sweet cherry, dandelion, grape, daisy, pansy, orchard grass) showed the specificity of the apple powdery mildew probes (PM-H2b, PM-H3L, PM-H3U, PM-H4) for Podosphaera leucotricha (Fig. 1). The probes reacted equally with apple and pear powdery mildew samples. Both diseases have been demonstrated to be caused by the same pathogen, P. leucotricha (32).

The apple scab probes (VI-H1b, VI$\mathrm{H} 2 \mathrm{~b}$, VI-H3b, VI-H4b) all worked well with pure cultures of V. inaequalis (Fig. 1). The specificity of these probes was demonstrated when they did not react with DNA from the closely related $V$. pirina species, but further testing of additional Venturia spp. should be conducted to give greater confidence in the specificity of the apple scab probes.

The nonspecific bacterial probes (Bact$\mathrm{H} 1$, Bact-H2, and Bact-H3) designed to act as controls detected most of the Erwinia amylovora isolates, but reacted with varying efficiency to the remainder of the bacterial species (Fig. 1). For example, BactH1 hybridized with all E. amylovora isolates, one Erwinia carotovora isolate, a Pantoea agglomerans isolate, and both Escherichia coli isolates. The probe Bact$\mathrm{H} 3$ only hybridized with two of the three E. amylovora isolates, one E. carotovora isolate (E-161), and a P. agglomerans isolate, but did not react with $E$. carotovora (E-1), Escherichia coli, Bacillus spp., or any of the Pseudomonas spp. Hybridization probes designed as positive controls for bacteria have been reported (8), but unfortunately they lie outside the region amplified by ITS-16 and ITS-23 primers used in this study. New bacterial positive control probes will therefore need to be designed to hybridize with more conserved DNA sequences to ensure all bacteria are targeted.

The E. amylovora probes (EA-H1, EA$\mathrm{H} 3 \mathrm{~d}$, and EA-H4C) varied in their levels of specificity likely because of slight ITS sequence variability within the species or possible confusion in identification of closely related species. Probe design utilized E. amylovora rDNA sequences obtained from GenBank (AF290418, AF290419, and AJ010485) as well as other bacterial species such as Erwinia pyrifoliae, E. rhapontici, Enterobacter pyrinus, Pantoea stewartii, and Escherichia coli. The ITS region allowed the design of two probes (EA-H1 and EA-H4C) specific for E. amylovora and a third probe that would react with both $E$. amylovora and $E$. pyrifoliae (EA-H3d). E. pyrifoliae is a pathogen of Asian pear closely related to $E$. amylovora (16). The probe sequences for EA-H1 and EA-H4C were $100 \%$ specific for $E$. amylovora when BLAST searches were conducted. However, they only reacted with two of the three E. amylovora test isolates (1280 and 1477.1) and did not react with the remaining isolate from pear (G-5). Isolate G-5 did however react with the E. amylovora and E. pyrifoliae probe (EA-H3d), which brings into question its correct identity.

Quantification of pathogen populations in plant tissue. Preliminary tests to 


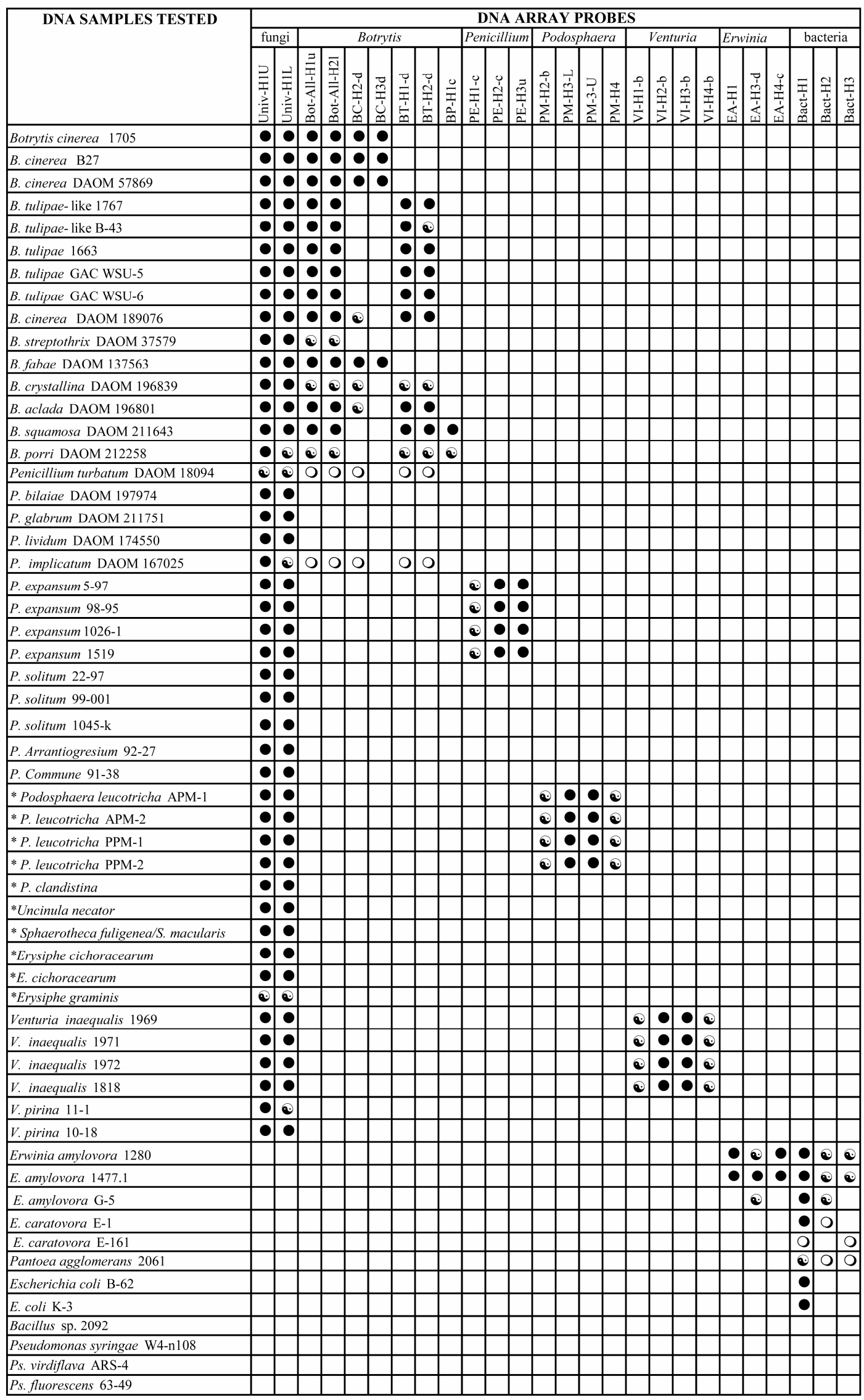

Fig. 1. Specificity of DNA array probes for targeted apple pathogens. Grayscale value for a strong reaction is denoted with a dark circle $(\bullet=150$ to 255$)$, for a medium reaction with a half-dark circle $(\odot=50$ to 150$)$, and for a faint reaction with a clear circle $(\mathrm{O}=0$ to 50$)$. 
assess quantitative capability of the array were conducted with Podosphaera leucotricha. These tests were also valuable in determining the detection limits of the array hybridization assay for P. leucotricha.

Known concentrations of $P$. leucotricha conidia were prepared and hybridized with the array to produce a standard series of grayscale values (Fig. 2). These grayscale values were compared with values from sterile leaf disk samples inoculated with an identical spore concentration prior to DNA extraction. The lower limit of detection for $P$. leucotricha conidia was shown to be in the order of $2 \times 10^{1}$ conidia per leaf disk. The leaf disk results were similar to DNA array detection of $P$. leucotricha conidia from spore trap I-rods collected from the field that were, prior to DNA extraction, determined microscopically as $3 \times 10^{1}$ conidia per I-rod.

Quantification studies with E. amylovora were conducted in 2002 using a

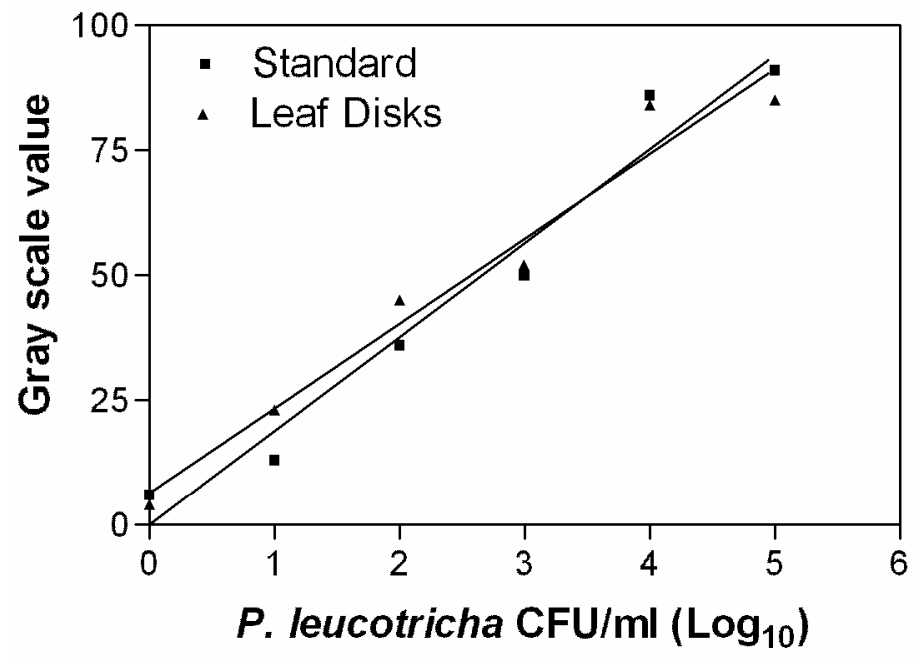

Fig. 2. DNA array detection and quantification of Podosphaera leucotricha. Array hybridization reactions of 0 to $10^{5} P$. leucotricha conidia per sample were converted to grayscale values to produce standard curves for $P$. leucotricha. Set concentrations of $P$. leucotricha conidia $\left(R^{2}=0.9628\right)$ and inoculated leaf disks with set concentrations of conidia $\left(R^{2}=0.9639\right)$ when hybridized and converted to grayscale values produced almost identical curves. The standard curves were used to determine cell numbers in unknown samples collected on spore traps.

method similar to that used for P. leucotricha and will appear in a future publication. Populations of E. amylovora were counted daily over a period of 5 days in 'Jonagold' blossoms by dilution plating and with the DNA array test. The two methods generally corresponded except that the DNA array was more sensitive in detecting populations less than $1,000 \mathrm{CFU} / \mathrm{ml}$. These two examples show that a DNA array detection system can be used in epidemiological studies for monitoring population levels of both obligate fungal and bacterial pathogens.

Field monitoring of apple scab, powdery mildew, and fire blight pathogens. The DNA array was used in field monitoring studies with spore trap samples to verify the presence of airborne pathogen spores in orchards. Apple scab infection periods and $V$. inaequalis ascospore counts were highly correlated to positive hybridization of V. inaequalis probes in 2002 (data not shown). Infection periods were predicted by the model for 20 to 23 May 2002. The peak count of ascospores was found on 24 May 2002. Positive hybridization occurred on 19,20,21, and 22 May 2002 corresponding directly to the ascospore release data. Scab symptoms were visible in the orchard on 6 June 2002. Similar results were obtained in 2003 with strong association between ascospore count and DNA array hybridization (Fig. $3)$. In several cases during the 2003 growing season, the DNA array detected the presence of $V$. inaequalis ascospores on dates that did not coincide with predicted infection periods. This likely was because

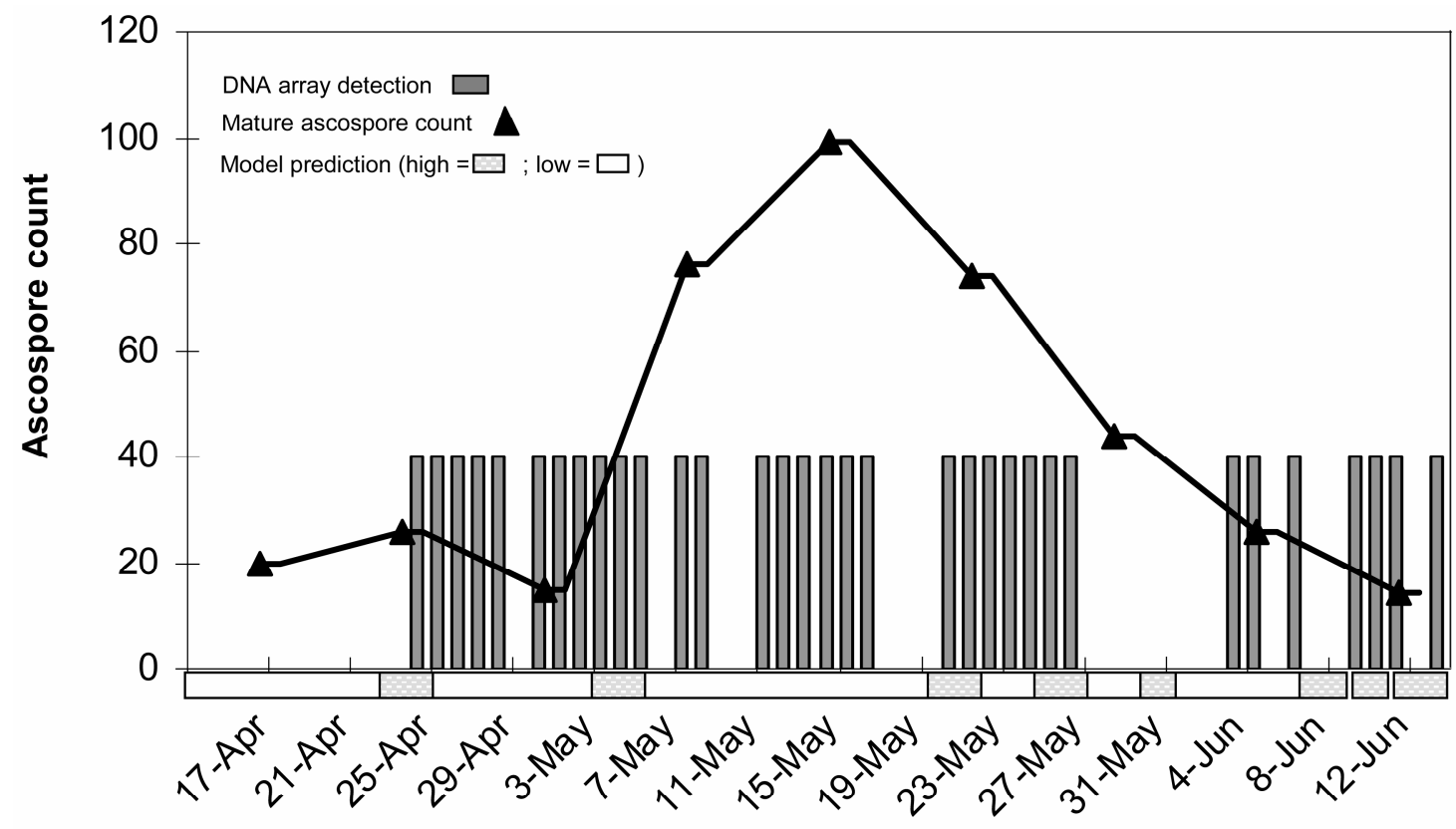

\section{Model prediction/DNA array detection of ascospore release}

Fig. 3. Association of Venturia inaequalis hybridization reactions from spore trap samples with corresponding results for ascospore counts released from leaves. Infection dates as predicted by three apple scab models (Spectrum Technologies, Plainfield, IL) monitored weekly over a 2-month period in 2003 are shown. 
the ascospores had been released by continuous irrigation of leaves in the vicinity of the spore trap over several days due to an operator error. DNA array detection was generally accompanied by increasing levels of mature ascospores. Future studies with the DNA array could use grayscale values to accurately indicate ascospore density for fine tuning apple scab disease forecasting models.

The weather instrumentation did not have an accompanying apple powdery mildew predictive model, but hybridization results were compared with the grape powdery mildew model. Positive hybridization results for $P$. leucotricha from spore trap samples occurred on 21 to 24 May 2002 and 3 to 7 June 2002. The grape powdery mildew model predicted heavy ascospore infection on 20 to 23 May 2002 and heavy conidial infection on 4 to 7 June 2002 (data not shown). This close association with the grape powdery mildew model was likely coincidental because $P$. leucotricha does not produce viable ascospores and overwinters as mycelium in the apple bud (14). A second year of monitoring for P. leucotricha at PARC, Summerland, and at the nearby Garnet Valley apple orchard (Fig. 4) was conducted in 2003. In both locations, P. leucotricha was detected prior to the release dates predicted by the grape powdery mildew model. Positive hybridization results were recorded through the bloom period and again in mid-June to September. Of interest were the periods of time when $P$. leucotricha was not detected. The reasons why this occurred are not known but could be related to the effect of microclimate on spore release. If these conditions of climate could be quantified, they could be useful in developing future apple powdery mildew models. Further
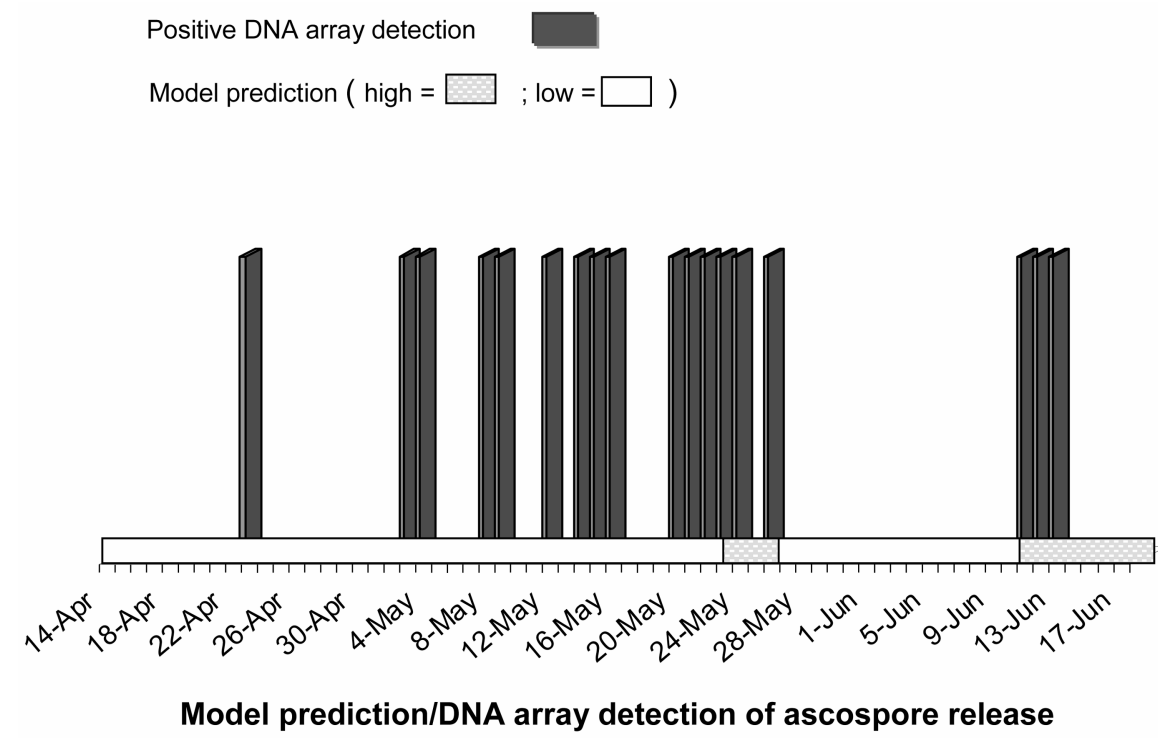

Fig. 4. Podosphaera leucotricha hybridization reactions from spore trap samples for 2003 for the Garnet Valley orchard monitored from green tip to small green fruit stage of apple development. Infection dates predicted by the grape powdery mildew model (Spectrum Technologies, Plainfield, IL) for ascospore infection are shown. conditions that lead to the absence of $P$. leucotricha in the orchard air.

Spore trap I-rods from an apple orchard were microscopically inspected and probed daily with the DNA array over a 1-week period from 8 to 12 July 2002. P. leucotricha and Botrytis spp. averaging 36 and 31 conidia, respectively, per rod per day were found. The hybridized DNA from these rods showed positive reactions for P. leucotricha, Botrytis spp., and Penicillium spp. Interestingly, Penicillium spp. were not observed on the I-rods by microscopic investigation, indicating that the DNA array was better for detecting the different genera present in orchard air than visual examination of I-rods. Possibly the other propagules on the I-rods hid the Penicillium spp. from view and the spores of possible that there are other species in the environment that may have cross-reacted with our probes. Further study will be needed to conclusively determine the cause.

The array did not detect E. amylovora from randomly sampled apple and pear blossoms collected from orchards with a past history of fire blight. The array did detect $E$. amylovora on leaves that were collected later in the growing season during or just following predicted infection periods in mid-May, mid-June, and again in early July. This indicates that the array could be used for early detection of $E$. amylovora.

The DNA array allows rapid screening and identification of several fungal and bacterial pathogens of apple collected from blossoms, leaves, and spore traps in one simple test. In this study, we have provided novel examples of how the DNA array can research will be needed to determine the Penicillium spp. were missed. It is also be used to identify and quantify both fungal and bacterial pathogens in the same test. The use of spore traps in conjunction with the DNA array for identification of airborne pathogens was successfully accomplished in apple orchards, producing results comparable to observation with a microscope. This research provides a blueprint for future work where DNA techniques such as those in this study could be used with spore traps to identify and quantify airborne pathogens in an orchard setting. Because of the sensitivity of the DNA macroarray, it should prove to be an effective research and extension tool for use in apple pest management for studies on epidemiology, biological control, and chemical control of plant pathogens.

\section{ACKNOWLEDGMENTS}

We thank the Washington Tree Fruit Research Commission and the Matching Investment Initiatives fund of Agriculture and Agri-Food Canada for financial support. We also thank Julie Boulé, Paula Haag, Sarah Stokes, and Lindsey Burke for technical assistance.

\section{LITERATURE CITED}

1. Bakkeren, G., Kronstad, J. W., and Lévesque, C. A. 2000. Comparison of AFLP fingerprints and ITS sequences as phylogenetic markers in Ustilaginomycetes. Mycologia 92:510-521.

2. Bruns, T. D., and Shefferson, R. P. 2004. Evolutionary studies of ectomycorrhizal fungi: Recent advances and future directions. Can. J. Bot. 82:1122-1132.

3. Calderon, C., Ward, E., Freeman, J., Foster, S. J., and McCartney, H. A. 2002. Detection of airborne inoculum of Leptosphaeria maculans and Pyrenopeziza brassicae in oilseed rape crops by polymerase chain reaction (PCR) assays. Plant Pathol. 51:303-310.

4. Call, D. R., Brockman, F. J., and Chandler, D. P. 2001. Detecting and genotyping Escherichia coli $\mathrm{O} 157: \mathrm{H} 7$ using multiplexed PCR and nucleic acid microarrays. Int. J. Food Microbiol. 67:71-80.

5. de Jong, S. N., Lévesque, C. A., Verkley, G. J. M., Abeln, E. C. A., Rahe, J. E., and Braun, P. G. 2001. Phylogenetic relationships among Neofabraea species causing tree cankers and bull's-eye rot of apple based on DNA sequencing of ITS nuclear rDNA, mitochondrial rDNA, and the $\beta$-tubulin gene. Mycol. Res. 105:658-669.

6. Edel, V. 1998. Polymerase chain reaction in mycology: An overview. Pages 1 to 20 in: Applications of PCR in Mycology. P. D. Bridge, D. K. Arora, C. A. Reddy, and R. P. Elander, eds. CAB International, Wallingford, Oxon, UK.

7. Felsenstein, J. 1985. Confidence limits on phylogenies: An approach using the bootstrap. Evolution 39:783-791.

8. Fessehaie, A., De Boer, S. H., and Lévesque, C. A. 2003. An oligonucleotide array for the identification and differentiation of bacteria pathogenic on potato. Phytopathology 93:262269.

9. Freeman, J., Ward, E., Calderon, C., and McCartney, A. 2002. A polymerase chain reaction (PCR) assay for the detection of inoculum of Sclerotinia sclerotiorum. Eur. J. Plant Pathol. 108:877-886.

10. Gadoury, D. M., and MacHardy, W. E. 1982. Preparation and interpretation of squash mounts of pseudothecia of Venturia inaequalis. Phytopathology 72:92-95.

11. Gardes, M., and Bruns, T. D. 1993. ITS primers with enhanced specificity for basidiomycetes - Application to the identification of my- 
corrhizae and rusts. Mol. Ecol. 2:113-118.

12. Gariépy, T. D., Lévesque, C. A., de Jong, S. N., and Rahe, J. E. 2003. Species specific identification of the Neofabraea pathogen complex associated with pome fruits using PCR and multiplex DNA amplification. Mycol. Res. 107:528-536.

13. Ginns, J. H. 1986. Compendium of Plant Disease and Decay Fungi in Canada, 19601980. Canadian Government Publishing Centre, Ottawa, ON.

14. Hickey, K. D., and Yoder, K. S. 1990. Powdery mildew. Pages 9-10 in: Compendium of Apple and Pear Diseases. A. L. Jones and H. S. Aldwinckle, eds. American Phytopathological Society, St. Paul, MN

15. Kawasaki, E., Saiki, R., and Erlich, H. 1993. Genetic analysis using polymerase chain reaction-amplified DNA and immobilized oligonucleotide probes: Reverse dot-blot typing. Methods Enzymol. 218:369-379.

16. Kim, W-S., Gardan, L., Rhim, S-L., and Geider, K. 1999. Erwinia pyrifoliae sp. nov., a novel pathogen that affects Asian pear trees (Pyrus pyrifolia Nakai). Int. J. Syst. Bacteriol. 49:899-906.

17. Lévesque, C. A., Harlton, C. E., and de Cock, A. W. A. M. 1998. Identification of some oomycetes by reverse dot blot hybridization. Phytopathology 88:213-222.

18. Lievens, B., Brouwer, M., Vanachter, A., Lévesque, C. A., Cammue, B., and Thomma, B. 2003. Design and development of a DNA array for rapid detection and identification of multiple tomato vascular wilt pathogens. FEMS Microbiol. Lett. 223:113-122.

19. Louws, F. J., Rademaker, J. L., and de Bruijn, F. J. 1999. The three Ds of PCR-Based genomic analysis of phytobacteria: Diversity, detection, and disease diagnosis. Annu. Rev. Phytopathol. 37:81-125.

20. Martin, R. R., James, D., and Lévesque, C. A. 2000. Impacts of molecular diagnostic technologies on plant disease management. Annu. Rev. Phytopathol. 38:207-239.

21. McCartney, H. A., Foster, S. J., Fraaife, B. A., and Ward, E. 2003. Molecular diagnostics for fungal plant pathogens. Pest Manag. Sci. 59:129-142.

22. McManus, P. S., and Jones, A. L. 1995. Detection of Erwinia amylovora by nested PCR and PCR-dot-blot and reverse-blot hybridizations. Phytopathology 85:618-623.

23. O'Donnell, K., Cigelnik, E., and Nirenberg, H. I. 1998. Molecular systematics and phylogeography of the Gibberella fujikuroi species complex. Mycologia 90:465-493.

24. O'Gorman, D., Bedford, K. E., Sholberg, P. L., Stokes, S. C., Haag, P., and Lévesque, C. A. 2003. Design and testing of a comprehensive DNA array diagnostic system for apple diseases. (Abstr.) Phytopathology 93:S66.

25. Pedersen, L. H., Skouboe, P., Boysen, M., Soule, J., and Rossen, L. 1997. Detection of Penicillium species in complex food samples using the polymerase chain reaction. Int. J. Food Microbiol. 35:169-177.

26. Pitt, J. I. 1979. The Genus Penicillium and its Teliomorphic States Eupenicillium and Talaromyces. Academic Press, London.

27. Saitou, N., and Nei, M. 1987. The neighborjoining method: A new method for reconstructing phylogenetic trees. Mol. Biol. Evol. 4:406425.

28. Samuels, G. J., and Seifert K. A. 1995. The impact of molecular characters on systematics of filamentous Ascomycetes. Annu. Rev. Phytopathol. 33:37-67.

29. Schnabel, G., Schnabel, E. L., and Jones, A. L. 1999. Characterization of ribosomal DNA from Venturia inaequalis and its phylogenetic relationship to rDNA from other tree-fruit Venturia species. Phytopathology 89:100-108.

30. Seifert, K. A., and Louis-Seize, G. 2000. Phylogeny and species concepts in the Penicillium aurantiogriseum complex as inferred from partial $\beta$-tubulin gene DNA sequences. Pages 189198 in: Integration of Modern Taxonomic Methods for Penicillium and Aspergillus Classification. R. A. Samson and J. I. Pitt, eds. Harwood Academic Publishers, The Netherlands.

31. Sholberg, P. L., Harlton, C., Haag, P., Lévesque, C. A., O'Gorman, D., and Seifert,
K. 2005. Benzimidazole and diphenylamine sensitivity and identity of Penicillium spp. that cause postharvest blue mold of apples using $\beta$ tubulin gene sequences. Postharv. Biol. Technol. 36:41-49.

32. Sholberg, P. L., O'Gorman, D. T., and Bedford, K. E. 2004. Use of PCR and DNA hybridization for identification of pear powdery mildew caused by Podosphaera leucotricha (Ell. \& Ev.) Salm. Can. J. Plant Pathol. 26:199 204.

33. Takamatsu, S., Hirata, T., and Sato, Y. 2000. A parasitic transition from trees to herbs occurred at least twice in tribe Cystotheceae (Erysiphaceae): Evidence from nuclear ribosomal DNA. Mycol. Res. 104:1304-1311.

34. Uehara, T., Kushida, A., and Momota, Y. 1999. Rapid and sensitive identification of Pratylenchus spp. using reverse dot blot hybridization. Nematology 1:549-555.

35. Utkhede, R. S., Lévesque, C. A., and Dinh, D. 2000. Pythium aphanidermatum root rot in hydroponically grown lettuce and the effect of chemical and biological agents on its control. Can. J. Plant Pathol. 22:138-144.

36. Voordouw, G., Shen, Y., Harrington, C. S Telang, A. J., Jack, T. R., and Westlake, D. W. S. 1993. Quantitative reverse sample genome probing of microbial communities and its application to oil field production waters. Appl. Environ. Microbiol. 59:4101-4114.

37. Ward, E., Foster, S. J., Fraaije, B. A., and McCartney, H. A. 2004. Plant pathogen diagnostics: Immunological and nucleic acid-based approaches. Ann. Appl. Biol. 145:1-16.

38. White, T. J., Bruns, T., Lee, S., and Taylor, J. 1990. Amplification and direct sequencing of fungal ribosomal RNA genes for pylogenetics. Pages 315-322 in: PCR Protocols: A Guide to Methods and Applications. M. A. Innis, D. H. Gelfand, J. J. Sninsky, and T. J. White, eds. Academic Press, San Diego, CA.

39. Williams, R. H., Ward, E., and McCartney, H. A. 2001. Methods for integrated air sampling and DNA analysis for detection of airborne fungal spores. Appl. Environ. Microbiol. 67:2453-2459. 